\title{
Direct medical costs of obesity in the United States and the most populous states
}

\author{
John Cawley, PhD; Adam Biener, PhD; Chad Meyerhoefer, PhD; Yuchen Ding, PhD; Tracy Zvenyach, PhD, NP; \\ B Gabriel Smolarz, MD, MS; and Abhilasha Ramasamy, MS
}

\section{What is already known about this subject}

- The prevalence of obesity has risen dramatically in the United States in the past several decades, leading to great interest in a better understanding of the medical care costs of obesity.

- Previous studies, using various research methods and data sources, have consistently shown that individuals with obesity have higher medical care costs than those without obesity.

\section{What this study adds}

- This study estimated the causal effects of obesity on medical care costs in the United States at both the national and state levels.

- Obesity doubled the medical expenditures of adults relative to those of normal weight and raised expenditures on inpatient care, outpatient care, and prescription drugs.

- Given that the causal effect of obesity on medical care costs was greater than earlier estimates based on correlations, interventions to prevent and reduce obesity may be more cost-effective than previously appreciated.

\section{Author affiliations}

John Cawley, PhD, Department of Policy Analysis and Management and Department of Economics, Cornell University, Ithaca, NY; Adam Biener, PhD, Department of Economics, Lafayette College, Easton, PA; Chad Meyerhoefer, PhD, College of Business, Lehigh University, Bethlehem, PA; Yuchen Ding, PhD, bluebird bio, Cambridge, MA; and Tracy Zvenyach, PhD, NP, Independent Advisor, Healthcare and Obesity Public Policy, Madison, WI. B Gabriel Smolarz, MD, MS, and Abhilasha Ramasamy, MS, Novo Nordisk, Plainsboro, NJ.

AUTHOR CORRESPONDENCE: John Cawley, 607.255.0952, johncawley@cornell.edu

J Manag Care Spec Pharm 2021;27(3):354-66

Copyright $(2021$, Academy of Managed Care Pharmacy. All rights reserved.

RESULTS: Adults with obesity in the United States compared with those with normal weight experienced higher annual medical care costs by $\$ 2,505$ or $100 \%$, with costs increasing significantly with class of obesity, from $68.4 \%$ for class 1 to $233.6 \%$ for class 3 . The effects of obesity raised costs in every category of care: inpatient, outpatient, and prescription drugs. Increases in medical expenditures due to obesity were higher for adults covered by public health insurance programs $(\$ 2,868)$ than for those having private health insurance $(\$ 2,058)$. In 2016 , the aggregate medical cost due to obesity among adults in the United States was $\$ 260.6$ billion. The increase in individual-level 
expenditures due to obesity varied considerably by state (e.g., $24.0 \%$ in Florida, $66.4 \%$ in New York, and $104.9 \%$ in Texas).

CONCLUSIONS: The 2-part models of instrumental variables, which estimate the causal effects of obesity on direct medical costs, showed that the effect of obesity is greater than suggested by previous studies, which estimated only correlations. Much of the aggregate national cost of obesity $-\$ 260.6$ billion-represents external costs, providing a rationale for interventions to prevent and reduce obesity.

The prevalence of obesity continues to rise in the United States, with more than $40 \%$ of U.S. adults living with obesity. ${ }^{1-4}$ Obesity is associated with an increased risk of many chronic medical conditions, including type 2 diabetes, cardiovascular disease, stroke, cancer, and asthma, as well as reduced life expectancy. ${ }^{5-7}$ Additionally, the effects of obesity impose a tremendous financial burden on health care systems. ${ }^{8-10}$ Higher medical care costs among individuals with obesity have been found for a variety of U.S. subgroups across various data samples using several different research methods. ${ }^{11-15}$

Previous research has shown that medical expenditures associated with obesity vary by state, both overall and by type of payer. ${ }^{16-20}$ For example, Biener et al. (2018) reported that the proportion of medical expenditures associated with obesity ranged from approximately $4 \%$ in California to $14 \%$ in North Carolina in 2015 , based on estimates from the Medical Expenditure Panel Survey (MEPS). ${ }^{16}$ Variation in the burden of obesity across states was due to multiple factors including obesity prevalence, differences in health care utilization among people with obesity, how obesity was treated, and the cost of services across states. ${ }^{16}$

Studies have found that health care costs associated with obesity increase with body mass index (BMI) and obesity class. A review of 33 U.S. studies found that perperson direct medical costs of obesity were more than 6 times greater than those for overweight, with aggregate costs estimated to be nearly \$114 billion. ${ }^{21}$ Andreyeva et al. (2004) found that costs were twice as high for those with a BMI greater than $40 \mathrm{~kg} / \mathrm{m}^{2}$ compared with adults of normal weight among a sample of adults aged 54-69 years. ${ }^{22}$ Similarly, Su et al. (2015) found a 3-fold increase in medical expenditures from class 1 obesity to class 3 obesity, where each kilogram of weight was associated with high average costs of $\$ 140$ annually. ${ }^{15}$

A limitation of these estimates is that they all are correlations of obesity with medical care costs. Due to reverse causality and omitted variables bias, the correlation between obesity and medical care costs can be very different from the causal effect of obesity on costs. For example, an injury or medical condition could lead to both higher medical care costs and the onset of obesity due to reduced mobility. Furthermore, obesity is more common among people of lower socioeconomic status, who generally have less access to care. These problems of reverse causality and omitted variables bias can be addressed using models of instrumental variables allowing one to estimate the causal effect of obesity on medical care costs. ${ }^{23,24}$ Such instrumental variables models using the BMI of biological relatives as "instruments" have been used to estimate the medical care costs of obesity among both adults and youth. ${ }^{25-28}$

Our study presents estimates of the total amount and percentage of medical care expenditures attributable to obesity. By using more recent data than previous analyses, ${ }^{27,28}$ we provide up-to-date national estimates. Importantly, this study contains the first causal estimates of obesity for the 4 most populous states: California, Texas, New York, and Florida. We estimate the effect of obesity on total medical care costs, as well as separately by obesity class, payer, and type of medical service. Collectively, the results represent the most up-to-date, comprehensive, and detailed evidence of the causal effect of obesity on direct medical care costs in the United States.

\section{Methods}

\section{TWO-PART MODEL}

Medical expenditures must be modeled using a 2-part model because a nontrivial number of individuals have zero medical expenditures, and among those who do have positive expenditures, those expenditures are highly positively skewed-a small number of individuals have very high medical expenditures. This study estimated 2-part models that accounted for those aspects of the distribution in the following ways: (a) the zeros were addressed in the first part of the model, in which a logit model estimated the probability of having any medical expenditures; and (b) the skewness in positive expenditures was addressed by the functional form of the second part of the model, which was a gamma generalized linear model with a log link function. ${ }^{29}$

Both parts of the model controlled for the following variables: gender, race/ethnicity, respondent age, education level, U.S. census region, residence in a metropolitan statistical area, household composition (number and age of household members), employment status, gender of the oldest child, age of the oldest child in months, marital status, health insurance plan enrollment, and health maintenance organization or managed care plan enrollment in 
addition to fixed effects for year and whether the data was self- or proxy-reported.

We estimated 2-part models for total medical expenditures, which included all spending on ambulatory and inpatient health care services and prescription drugs from out-of-pocket and third-party sources (private insurance, Medicaid, Medicare, and other state, local, and military public programs), and other expenditures such as durable medical equipment, vision, and home health care. We also estimated 2-part models for medical expenditures on specific categories of care: ambulatory care, inpatient services, and prescription drugs (excluding antiobesity medications or AOMs). We omitted antiobesity medications because if one wanted to use the estimates in this paper to assess the business case for covering AOMs, they would not want to include the cost of AOMs. However, including or excluding AOMs has very little effect on the estimates.

\section{METHOD OF INSTRUMENTAL VARIABLES}

We used the method of instrument variables to estimate both parts of the 2-part model. The parameters in the instrumental variables model were identified using variation in BMI due to differences in genetic heritability, which was not correlated with unobservable factors that determine medical expenditure. This allowed the model to estimate the causal effect of BMI on medical expenditures. Valid instruments should satisfy 2 conditions: (1) the instrument must be powerful (i.e., strongly correlated with the independent variable of interest, in this case, respondent BMI); and (2) the instrument must be valid (i.e., uncorrelated with residual medical expenditures, which is referred to as the exclusion restriction). In our case, the exclusion restriction meant that the instrument should not be correlated with any unobserved factors that may affect respondent medical expenditures.

Our instrument for respondent BMI was the BMI of their biological child. This takes advantage of the natural experiment of the heritability of weight-that some people are endowed with a greater genetic propensity to have a high BMI. A large scientific literature demonstrated that BMI and obesity have a strong genetic component; thus, the biological child's BMI is strongly correlated with the BMIs of the parents. ${ }^{30-32}$ This indicated that the instrument was likely to be a powerful one (condition 1 above). We confirmed this by using an F statistic to measure the power of the instrument in the first stage of the instrumental variables model; the F statistic was 2,088.66, which was far above the rule of thumb of $\mathrm{F}>10$ for a sufficiently powerful instrument.

Although it is impossible to prove the validity of an instrument, our identification strategy is supported by extensive literature in behavioral genetics concluding that variation in obesity is mostly due to differences in genes and individual environment. One might be concerned that common household environment could affect both child BMI and parental medical expenditures, causing bias in our instrumental variables models, but the genetics literature on obesity has generally found a common household environment effect on BMI only at young ages, which disappears by adolescence..$^{33}$ As all children in the analysis were aged 11-19 years, the effect of a common environment on youth BMI should be minimized.

Alternatively, one might be concerned that parent BMI could influence both the household environment and the child's BMI (e.g., a lack of emphasis on physical activity by the parent leads to the child being less physically active and more susceptible to obesity). Since parent and child BMI are similar due to their shared genes, this was difficult to test. However, tests of genetic nurture have found that parental genes that influence the parents' BMIs that were not inherited by the child had no detectable effect on the child's BMI, suggesting parental BMI does not affect child BMI through the household environment. ${ }^{34,35}$ Another concern was that genes that determine BMI may affect other characteristics that determine medical expenditures (pleiotropy). The genetics literature finds that genes that affect BMI only affect BMI's components and obesity-related illnesses, but not characteristics unrelated to obesity, ${ }^{36,37}$ which is consistent with instrument validity.

In addition, we conducted an overidentification test to verify whether the instrument met the exclusion restriction. Multiple instruments were required to perform the overidentification test, so we used the level, square, and cube of child BMI ( $F=751.76$ for this instrument set). The Hansen J statistic for the overidentification test was 3.47 $(P=0.18)$, indicating that we could not reject the null hypothesis that the instrument was uncorrelated with residual medical expenditures.

\section{ESTIMATING THE EFFECT OF OBESITY}

We calculated the average marginal effect of obesity on medical expenditures in 3 steps: (1) predict the medical expenditures for the mean BMI among individuals with normal weight (BMI $18.5-<25 \mathrm{~kg} / \mathrm{m}^{2}$ ) using the 2-part model, (2) predict the medical expenditures for the mean BMI among individuals with obesity (BMI $\left.\geq 30 \mathrm{~kg} / \mathrm{m}^{2}\right)$ using the 2-part model, and (3) subtract the predicted medical expenditures for individuals with normal weight from those for individuals with obesity. Since MEPS data are collected using a stratified multistage probability design, we accounted for this complex survey design in the calculation of standard errors for our marginal effects using balanced repeated replications and Fay's method. ${ }^{38-40}$ We estimated 
total national aggregate medical expenditures attributable to obesity using predicted total individual medical expenditures from our models and the sample weights from the MEPS designed to allow aggregation at state and national levels. We report all monetary estimates in 2017 U.S. dollars.

\section{DATA}

Our models were estimated using data from the MEPS, a nationally representative survey of the U.S. civilian, noninstitutionalized population. The study sample was a pooled cross-section (different respondents appear in different survey panels every 2 years) from the 2001-2016 MEPS. Institutional review board approval was not required, since MEPS is a publicly available household survey funded by the U.S. Agency for Healthcare Research and Quality for research purposes, and deidentified restricted-use data are accessed through the AHRQ MEPS Data Center.

Families participating in the MEPS provided information on "demographic characteristics, health conditions, health status, use of medical services, charges and source of payments, access to care, satisfaction with care, health insurance coverage, income, and employment" for all members of their household 5 times over a 2-year period. ${ }^{41}$ The Medical Provider Component collected medical expenditure and utilization data directly from participants' medical service providers and pharmacies, which were used to verify the data reported by households. BMI was calculated using self-reported or proxy-reported (for another household member) height and weight. Obesity was defined as $\mathrm{BMI} \geq 30 \mathrm{~kg} / \mathrm{m}^{2}$ and divided into classes for adults: class 1 (BMI $\left.30-<35 \mathrm{~kg} / \mathrm{m}^{2}\right)$, class 2 (BMI $\left.35-<40 \mathrm{~kg} / \mathrm{m}^{2}\right)$, and class $3\left(\mathrm{BMI} \geq 40 \mathrm{~kg} / \mathrm{m}^{2}\right)$. We used the continuous value of BMI of the child, not the child's clinical weight classification, as an instrument.

Our instrumental variables model required data on the BMI of a biological child, so we restricted our sample to adults aged 24-65 years with a biological child living in the household. The maximum age of 65 years reflected the lack of adults older than age 65 with a biological child living in the household. For the instrument of the BMI of a biological child, the children were between the ages of 11 and 19 years; we did not use younger children due to low response rates among such participants and to avoid any risk of common household environment affecting the child's BMI. When multiple children resided in the household, the eldest child with valid BMI data was used.

Observations were dropped if BMI data were missing for either parent or the biological child, as the instrumental variables model required both. Pregnant women were excluded to avoid conflating weight gain from pregnancy with obesity. Individuals with underweight $\left(\mathrm{BMI}<18.5 \mathrm{~kg} / \mathrm{m}^{2}\right)$ were dropped from the sample to focus on the effects of obesity and better predict the nonlinear changes in medical expenditures with higher levels of BMI. We excluded 2 individuals with extremely high medical expenditures (e.g., > $\$ 500,000)$ as outliers. Excluding those 2 outliers had negligible effect on the point estimates but considerably improved the precision of the model.

Our state-level analysis was limited to the 20 most populous states (AZ, CA, FL, GA, IL, KY, MD, MA, MI, MN, MO, NJ, $\mathrm{NY}, \mathrm{NC}, \mathrm{OH}, \mathrm{PA}, \mathrm{TX}, \mathrm{VA}, \mathrm{WA}$, and WI)-those with enough respondents in the MEPS to permit separate estimation of the 2-part instrumental variables model. Further, due to limited sample sizes among some of these states, we focused on the 4 largest states for which statistical power was sufficient to generate precise estimates (CA, TX, NY, and FL). Estimates were considered statistically significant if $\mathrm{P}<0.1$.

\section{Results}

\section{SUMMARY STATISTICS}

Descriptive statistics for control variables used in the analysis for the study sample (all states combined) are presented in Table 1 . The study sample included 63,508 adult respondents with at least 1 biological child in the household. In the study sample, $84 \%$ of the adults incurred positive medical expenditures during the year when they were surveyed. Among them, annual medical expenditures averaged $\$ 4,190$. The average BMI of the adult respondents was $28.46 \mathrm{~kg} / \mathrm{m}^{2}$.

\section{EFFECT OF BMI AND OBESITY ON MEDICAL EXPENDITURE AT NATIONAL LEVEL}

Results of the 2-part model of instrumental variables indicated that 1 additional unit of BMI raised the total annual medical expenditures by $\$ 201(90 \% \mathrm{CI}=\$ 149.37-\$ 251.89)$, which represented $5.4 \%$ of the annual mean predicted expenditures (Supplementary Table 1, available in online article). As shown in Table 2, the effects of obesity raised total annual medical expenditures by $\$ 2,505$ for U.S. adults. Thus, the annual medical care expenditures of adults with obesity $(\$ 5,010)$ were double that of people with normal weight $(\$ 2,504)$. The effect of excess weight on annual medical care costs at the individual level increased significantly with class of obesity; relative to those with normal weight, the additional expenditures due to obesity rose from $\$ 1,713$ (a $68.4 \%$ increase) for class 1 obesity to $\$ 3,005$ for class 2 obesity, (a $120.0 \%$ increase) to $\$ 5,850$ (a $233.6 \%$ increase) for class 3 obesity. 


\section{TABLE 1 Descriptive Statistics for Variables Used in the Direct Medical Care Cost Models (National Level and Top 4 Most Populous States)}

\begin{tabular}{|c|c|c|c|c|c|c|}
\hline \multirow{2}{*}{$\begin{array}{l}\text { Variable } \\
\text { Respondent, mean (SD) }\end{array}$} & United States & California & Texas & Florida & \multicolumn{2}{|c|}{ New York } \\
\hline & & & & & & \\
\hline \multicolumn{7}{|l|}{ Has positive expenditures } \\
\hline All medical & $(0.37)$ & $(0.49)$ & $(0.50)$ & $(0.40)$ & 0.84 & $(0.35)$ \\
\hline Private insurance & $(0.48)$ & $(0.59)$ & $(0.57)$ & $(0.50)$ & 0.62 & $(0.46)$ \\
\hline Medicaid & $(0.32)$ & $(0.41)$ & $(0.23)$ & $(0.30)$ & 0.16 & $(0.35)$ \\
\hline Out-of-pocket & $(0.41)$ & $(0.54)$ & $(0.52)$ & $(0.43)$ & 0.77 & $(0.40)$ \\
\hline Third party & $(0.42)$ & $(0.54)$ & $(0.55)$ & $(0.45)$ & 0.80 & $(0.38)$ \\
\hline Ambulatory & $(0.45)$ & $(0.56)$ & $(0.55)$ & $(0.47)$ & 0.75 & $(0.41)$ \\
\hline Inpatient & $(0.21)$ & $(0.20)$ & $(0.22)$ & $(0.24)$ & 0.05 & $(0.20)$ \\
\hline Prescription drug & $(0.48)$ & $(0.59)$ & $(0.56)$ & $(0.49)$ & 0.60 & $(0.47)$ \\
\hline Prescription drug excluding AOM & $(0.48)$ & $(0.59)$ & $(0.56)$ & $(0.49)$ & 0.60 & $(0.47)$ \\
\hline AOM prescription drug & $0.003 \quad(0.06)$ & $0.001 \quad(0.04)$ & $0.004 \quad(0.07)$ & $(0.08)$ & 0.001 & $(0.03)$ \\
\hline \multicolumn{7}{|l|}{ Total expenditures (USD, thousands)a } \\
\hline All medical & $4.19 \quad(10.61)$ & $3.40 \quad(10.58)$ & $3.58 \quad(10.91)$ & $4.12 \quad(10.11)$ & 4.52 & (12.36) \\
\hline Private insurance & $(9.33)$ & $(8.29)$ & $3.11 \quad(10.29)$ & $(8.89)$ & 3.87 & (11.74) \\
\hline Medicaid & $3.40 \quad(10.72)$ & $2.74 \quad(14.34)$ & $(9.59)$ & $(8.98)$ & 3.09 & $(9.82)$ \\
\hline Out-of-pocket & $(1.51)$ & $(1.94)$ & $(2.11)$ & $(1.44)$ & 0.69 & $(1.19)$ \\
\hline Third party & $3.78 \quad(10.49)$ & $3.06 \quad(10.36)$ & $3.29 \quad(10.74)$ & $3.76 \quad(10.14)$ & 4.10 & $(12.35)$ \\
\hline Ambulatory & $2.09 \quad(5.37)$ & $(4.92)$ & $(4.62)$ & $(6.47)$ & 2.04 & $(4.52)$ \\
\hline Inpatient & $16.36 \quad(25.00)$ & $17.40 \quad(30.15)$ & $17.42 \quad(33.63)$ & $13.90 \quad(18.30)$ & 23.72 & $(40.50)$ \\
\hline Prescription drug & $(4.66)$ & $(4.95)$ & $(3.01)$ & (3.33) & 1.39 & $(3.59)$ \\
\hline Prescription drug excluding AOM & $(4.79)$ & $(4.95)$ & $(3.01)$ & $(3.34)$ & 1.39 & $(3.59)$ \\
\hline AOM prescription drug & $(0.10)$ & $(0.13)$ & $(0.10)$ & $(0.03)$ & 0.14 & $(0.05)$ \\
\hline BMI $\left(\mathrm{kg} / \mathrm{m}^{2}\right)$ & $(6.17)$ & $(6.66)$ & 29.21 & 28.25 & 27.84 & $(5.66)$ \\
\hline Female & $(0.50)$ & $(0.59)$ & $(0.56)$ & $(0.49)$ & 0.58 & $(0.47)$ \\
\hline \multicolumn{7}{|l|}{ Race/ethnicity } \\
\hline White & $(0.48)$ & $(0.56)$ & $(0.56)$ & $(0.50)$ & 0.61 & $(0.46)$ \\
\hline African American & $(0.32)$ & $(0.27)$ & $(0.34)$ & $(0.37)$ & 0.15 & $(0.34)$ \\
\hline Hispanic & $(0.38)$ & $(0.59)$ & $(0.57)$ & $(0.44)$ & 0.17 & $(0.36)$ \\
\hline Other & $(0.25)$ & $(0.45)$ & $(0.26)$ & $(0.21)$ & 0.07 & $(0.24)$ \\
\hline \multicolumn{7}{|l|}{ Age (years) } \\
\hline $35-44$ & $(0.50)$ & $(0.58)$ & $(0.57)$ & $(0.50)$ & 0.40 & $(0.47)$ \\
\hline $45-54$ & $(0.49)$ & $(0.59)$ & $(0.54)$ & $(0.49)$ & 0.45 & $(0.47)$ \\
\hline 55 and older & $(0.27)$ & $(0.33)$ & $(0.28)$ & $(0.26)$ & 0.09 & $(0.27)$ \\
\hline \multicolumn{7}{|l|}{ Number of persons in the household } \\
\hline Aged $0-5$ years & $(0.45)$ & $(0.58)$ & $(0.56)$ & $(0.38)$ & 0.13 & $(0.38)$ \\
\hline Aged $11-17$ years & $(1.03)$ & $(1.21)$ & $(1.15)$ & $(0.92)$ & 1.52 & $(0.95)$ \\
\hline Aged $18-64$ years & $(0.88)$ & $(1.19)$ & $(1.02)$ & $(0.85)$ & 2.40 & $(0.88)$ \\
\hline Aged 65 years and older & $(0.22)$ & $(0.35)$ & $(0.29)$ & $(0.27)$ & 0.04 & $(0.22)$ \\
\hline
\end{tabular}




\section{TABLE 1 Descriptive Statistics for Variables Used in the Direct Medical Care Cost Models (National Level and Top 4 Most Populous States) (continued)}

\begin{tabular}{|c|c|c|c|c|c|c|c|c|c|c|}
\hline \multirow{2}{*}{$\begin{array}{l}\text { Variable } \\
\text { Married }\end{array}$} & \multicolumn{2}{|c|}{ United States } & \multicolumn{2}{|c|}{ California } & \multicolumn{2}{|c|}{ Texas } & \multicolumn{2}{|c|}{ Florida } & \multicolumn{2}{|c|}{ New York } \\
\hline & 0.79 & $(0.41)$ & 0.79 & $(0.49)$ & 0.81 & $(0.44)$ & 0.75 & $(0.44)$ & 0.77 & $(0.4)$ \\
\hline \multicolumn{11}{|l|}{ Education level ${ }^{\mathrm{b}}$} \\
\hline Less than high school diploma & 0.14 & $(0.35)$ & 0.24 & $(0.51)$ & 0.24 & $(0.48)$ & 0.11 & $(0.32)$ & 0.13 & $(0.33)$ \\
\hline High school graduate & 0.30 & $(0.46)$ & 0.24 & $(0.51)$ & 0.28 & $(0.51)$ & 0.31 & $(0.46)$ & 0.31 & $(0.44)$ \\
\hline Some college & 0.26 & $(0.45)$ & 0.24 & $(0.5)$ & 0.24 & $(0.49)$ & 0.31 & $(0.46)$ & 0.23 & $(0.40)$ \\
\hline College graduate & 0.29 & $(0.45)$ & 0.27 & $(0.53)$ & 0.24 & $(0.49)$ & 0.27 & $(0.44)$ & 0.33 & $(0.45)$ \\
\hline Urban & 0.84 & $(0.37)$ & 0.96 & $(0.24)$ & 0.91 & $(0.33)$ & 0.97 & $(0.16)$ & 0.88 & $(0.31)$ \\
\hline \multicolumn{11}{|l|}{ Census region } \\
\hline Northeast & 0.18 & $(0.39)$ & & & & & & & & \\
\hline Midwest & 0.22 & $(0.42)$ & & & & & & & & \\
\hline South & 0.36 & $(0.48)$ & & & & & & & & \\
\hline West & 0.23 & $(0.42)$ & & & & & & & & \\
\hline Self-reporting survey information & 0.59 & $(0.49)$ & 0.56 & $(0.59)$ & 0.58 & $(0.56)$ & 0.6 & $(0.49)$ & 0.58 & $(0.47)$ \\
\hline Employed & 0.85 & $(0.36)$ & 0.83 & $(0.45)$ & 0.85 & $(0.4)$ & 0.85 & $(0.36)$ & 0.84 & $(0.35)$ \\
\hline \multicolumn{11}{|l|}{ Health insurance } \\
\hline HMO or managed care & 0.33 & $(0.47)$ & 0.50 & $(0.59)$ & 0.22 & $(0.47)$ & 0.33 & $(0.47)$ & 0.47 & $(0.48)$ \\
\hline Private insurance & 0.76 & $(0.43)$ & 0.68 & $(0.55)$ & 0.70 & $(0.52)$ & 0.74 & $(0.44)$ & 0.74 & $(0.42)$ \\
\hline Medicare & 0.02 & $(0.13)$ & 0.01 & $(0.14)$ & 0.01 & $(0.12)$ & 0.02 & $(0.13)$ & 0.01 & $(0.11)$ \\
\hline Medicaid & 0.11 & $(0.31)$ & 0.17 & $(0.44)$ & 0.04 & $(0.21)$ & 0.09 & $(0.28)$ & 0.17 & $(0.36)$ \\
\hline \multicolumn{11}{|c|}{ Eldest child in the household with valid BMI } \\
\hline BMI $\left(\mathrm{kg} / \mathrm{m}^{2}\right)$ & 22.55 & $(5.11)$ & 22.52 & $(5.92)$ & 22.74 & $(5.85)$ & 22.67 & $(5.07)$ & 22.41 & $(4.91)$ \\
\hline Female & 0.48 & $(0.50)$ & 0.48 & $(0.59)$ & 0.48 & $(0.57)$ & 0.48 & $(0.50)$ & 0.49 & $(0.48)$ \\
\hline Age (months) & 191.33 & $(30.81)$ & 192.74 & $(36.95)$ & 189.43 & $(35.84)$ & 192.21 & (29.72) & 192.13 & (28.09) \\
\hline Observations, $\mathrm{n}$ & & 508 & & 870 & & 09 & & 43 & & 394 \\
\hline
\end{tabular}

Note: Data are from the 2001-2016 MEPS. Means and SDs are adjusted for the complex design of the MEPS.

a Mean total medical expenditures are conditional on having positive medical expenditures.

${ }^{b}$ Data for missing education not shown. This accounts for $<1 \%$ for some states.

$A O M=$ antiobesity medication; $B M I=$ body mass index; $H M O=$ health maintenance organization; $M E P S=$ Medical Expenditure Panel Surveys; SD=standard deviation; USD = United States dollar.

\section{MEDICAL EXPENDITURES BY PAYER AT NATIONAL LEVEL}

The marginal effect of an additional unit of BMI on annual expenditures paid by public insurance was particularly large: $\$ 240$, or $6.9 \%$ of the annual mean predicted expenditures. In contrast, an additional unit of BMI raised annual expenditures paid by private insurance by $\$ 163$, (5.4\%). Similarly, the increase in medical expenditures of adults with obesity compared with those with normal weight covered by public health insurance payments $(\$ 2,877)$ was greater than for those having private health insurance (\$2,058; Table 3). Out-of-pocket costs due to the effects of obesity paid by individuals, estimated at $\$ 229$, represented a small fraction of the increase in total annual costs.

\section{MEDICAL EXPENDITURES BY TYPE OF SERVICE AT NATIONAL LEVEL}

Obesity raised total medical expenditures (i.e., by all payers combined) on all types of medical services. Adults with obesity incurred an increase in expenditures for inpatient services of $\$ 1,088$ (289.8\%) when compared with those of adults with normal weight (\$1,463 vs. \$375). Additionally, the effects of obesity increased ambulatory care expenditures by $\$ 787$ or $67.0 \%$ and increased prescription drug 


\section{TABLE 3 Predicted Mean Expenditures and Average Marginal Effect of Obesity on Medical Expenditure} in the United States and Separately for the Top 4 Most Populous States, by Payer

\begin{tabular}{|c|c|c|c|c|c|c|c|c|}
\hline & \multicolumn{2}{|c|}{ Total Medical Expenditures } & \multicolumn{2}{|c|}{ Private Payments } & \multicolumn{2}{|c|}{ Public Payments } & \multicolumn{2}{|c|}{ Out-of-Pocket Payments } \\
\hline & $\begin{array}{l}\text { Normal } \\
\text { Weight }\end{array}$ & Obesity & $\begin{array}{l}\text { Normal } \\
\text { Weight }\end{array}$ & Obesity & $\begin{array}{l}\text { Normal } \\
\text { Weight }\end{array}$ & Obesity & $\begin{array}{l}\text { Normal } \\
\text { Weight }\end{array}$ & Obesity \\
\hline \multicolumn{9}{|c|}{ United States - National-level data } \\
\hline \multicolumn{9}{|c|}{$2001-2016(n=63,508)$} \\
\hline $\begin{array}{l}\text { Predicted mean } \\
\text { expenditures }\end{array}$ & $\begin{array}{l}2,504.48 \\
(2,280.31 \\
2,728.66)\end{array}$ & $\begin{array}{r}5,009.82 \\
(4,595.12 \\
5,424.51)\end{array}$ & $\begin{array}{l}2,076.09 \\
(1,841.67 \\
2,310.50)\end{array}$ & $\begin{array}{l}4,134.55 \\
(3,670.67 \\
4,598.44)\end{array}$ & $\begin{array}{l}1,652.21 \\
(1,211.27 \\
2,093.15)\end{array}$ & $\begin{array}{r}4,529.06 \\
(3,696.12 \\
5,361.99)\end{array}$ & $\begin{array}{l}508.28 \\
(466.79 \\
549.77)\end{array}$ & $\begin{array}{l}737.64 \\
(663.08 \\
812.19)\end{array}$ \\
\hline $\begin{array}{l}\text { Average marginal } \\
\text { effect }\end{array}$ & - & $\begin{array}{r}2,505.34 \\
(1,908.74 \\
3,101.94)\end{array}$ & - & $\begin{array}{r}2,058.46 \\
(1,402.34, \\
2,714.59)\end{array}$ & - & $\begin{array}{c}2,876.85 \\
(1,666.59 \\
4,087.1)\end{array}$ & - & $\begin{array}{r}229.36 \\
(118.67 \\
340.05)\end{array}$ \\
\hline \multicolumn{9}{|l|}{$2001-2005(n=21,024)$} \\
\hline $\begin{array}{l}\text { Predicted mean } \\
\text { expenditures }\end{array}$ & $\begin{array}{l}2,255.74 \\
(2,071.10 \\
2,440.39)\end{array}$ & $\begin{array}{c}4,531.00 \\
(4,094.69 \\
4,967.30)\end{array}$ & $\begin{array}{l}1,834.42 \\
(1,645.17 \\
2,023.67)\end{array}$ & $\begin{array}{r}3,610.15 \\
(3,158.46 \\
4,061.84)\end{array}$ & $\begin{array}{l}1,550.82 \\
(1,154.98 \\
1,946.65)\end{array}$ & $\begin{array}{c}4,295.01 \\
(3,382.76 \\
5,207.26)\end{array}$ & $\begin{array}{l}544.20 \\
(504.20 \\
584.21)\end{array}$ & $\begin{array}{c}824.39 \\
(722.89 \\
925.9)\end{array}$ \\
\hline $\begin{array}{l}\text { Average marginal } \\
\text { effect }\end{array}$ & - & $\begin{array}{c}2,275.25 \\
(1,701.48 \\
2,849.03)\end{array}$ & - & $\begin{array}{c}1,775.73 \\
(1,176.68 \\
2,374.77) \\
\end{array}$ & - & $\begin{array}{l}2,744.19 \\
(1,532.87 \\
3,955.51)\end{array}$ & - & $\begin{array}{c}280.19 \\
(145.82 \\
414.56)\end{array}$ \\
\hline \multicolumn{9}{|l|}{$2006-2010(n=19,199)$} \\
\hline $\begin{array}{l}\text { Predicted mean } \\
\text { expenditures }\end{array}$ & $\begin{array}{l}2,502.57 \\
(2,260.07 \\
2,745.06)\end{array}$ & $\begin{array}{c}5,060.36 \\
(4,592.16 \\
5,528.56)\end{array}$ & $\begin{array}{c}2,134.83 \\
(1,884.60 \\
2,385.07)\end{array}$ & $\begin{array}{c}4,186.31 \\
(3,676.41 \\
4,696.22)\end{array}$ & $\begin{array}{c}1,578.74 \\
(1,062.54 \\
2,094.93)\end{array}$ & $\begin{array}{c}4,435.43 \\
(3,554.49 \\
5,316.38)\end{array}$ & $\begin{array}{c}512.89 \\
(464.74 \\
561.04)\end{array}$ & $\begin{array}{c}784.38 \\
(692.57 \\
876.2) \\
\end{array}$ \\
\hline $\begin{array}{l}\text { Average marginal } \\
\text { effect }\end{array}$ & - & $\begin{array}{c}2,557.8 \\
(1,926.81 \\
3,188.79)\end{array}$ & - & $\begin{array}{c}2,051.48 \\
(1,368.18 \\
2,734.78)\end{array}$ & - & $\begin{array}{c}2,856.69 \\
(1,676.72 \\
4,036.67)\end{array}$ & - & $\begin{array}{c}271.49 \\
(145.21 \\
397.77)\end{array}$ \\
\hline \multicolumn{9}{|l|}{$2011-2016(n=23,285)$} \\
\hline $\begin{array}{l}\text { Predicted mean } \\
\text { expenditures }\end{array}$ & $\begin{array}{c}2,695.77 \\
(2,398.60 \\
2,992.94) \\
\end{array}$ & $\begin{array}{c}5,477.37 \\
(4,990.48 \\
5,964.25) \\
\end{array}$ & $\begin{array}{c}2,260.32 \\
(1,945.67 \\
2,574.96)\end{array}$ & $\begin{array}{c}5,477.37 \\
(4,990.48 \\
5,964.25)\end{array}$ & $\begin{array}{c}1,777.76 \\
(1,314.41 \\
2,241.11)\end{array}$ & $\begin{array}{c}4,861.83 \\
(3,852.43 \\
5,871.23) \\
\end{array}$ & $\begin{array}{l}446.55 \\
(398.47 \\
494.63)\end{array}$ & $\begin{array}{r}689.59 \\
(617.33 \\
761.86)\end{array}$ \\
\hline $\begin{array}{l}\text { Average marginal } \\
\text { effect }\end{array}$ & - & $\begin{array}{l}2,781.60 \\
(2,119.78 \\
3,443.42)\end{array}$ & - & $\begin{array}{c}2,781.6 \\
(2,119.78 \\
3,443.42)\end{array}$ & - & $\begin{array}{l}3,084.07 \\
(1,727.64 \\
4,440.51)\end{array}$ & - & $\begin{array}{l}243.04 \\
(135.63 \\
350.45)\end{array}$ \\
\hline
\end{tabular}

continued on next page

expenditures by $\$ 917$ or $186.8 \%$ (excluding antiobesity medications). For all types of services, the effect of excess weight on annual medical care costs at the individual level increased significantly with class of obesity; the greatest increase was for inpatient services, which was $177.6 \%$ and 923.9\% for class 1 and class 3 obesity, respectively.

\section{AGGREGATE MEDICAL EXPENDITURES DUE TO ADULT OBESITY AT NATIONAL LEVEL}

The total direct medical costs of obesity in adults more than doubled during the study period, from \$124.2 in 2001 to $\$ 260.6$ billion in 2016 (Table 4). In 2016, \$139.4 billion was paid by private health insurance, $\$ 57.9$ billion was paid by public health insurance programs, and $\$ 20.0$ billion was paid out of pocket by patients for obesity-related care.

\section{EFFECT OF BMI AND OBESITY ON MEDICAL EXPENDITURES AT STATE LEVEL}

The increase in total annual medical expenditure by an additional unit of BMI varied greatly by state (Supplementary Table 1, available in online article); among the top 4 most populous states, the increase was $\$ 55$ in Florida (not statistically significant), \$152 in New York, \$153 in Texas, and \$373 in California. There were also large differences between states regarding the increase in total medical expenditures due to obesity (Table 2, for the top 4 most populous states, 


\section{TABLE 3 Predicted Mean Expenditures and Average Marginal Effect of Obesity on Medical Expenditure in the United States and Separately for the Top 4 Most Populous States, by Payer (continued)}

\begin{tabular}{|c|c|c|c|c|c|c|c|c|}
\hline & \multicolumn{2}{|c|}{ Total Medical Expenditures } & \multicolumn{2}{|c|}{ Private Payments } & \multicolumn{2}{|c|}{ Public Payments } & \multicolumn{2}{|c|}{ Out-of-Pocket Payments } \\
\hline & $\begin{array}{l}\text { Normal } \\
\text { Weight }\end{array}$ & Obesity & $\begin{array}{l}\text { Normal } \\
\text { Weight }\end{array}$ & Obesity & $\begin{array}{l}\text { Normal } \\
\text { Weight }\end{array}$ & Obesity & $\begin{array}{l}\text { Normal } \\
\text { Weight }\end{array}$ & Obesity \\
\hline \multicolumn{9}{|l|}{ State-level data } \\
\hline \multicolumn{9}{|l|}{ California $(n=10,870)$} \\
\hline $\begin{array}{l}\text { Predicted mean } \\
\text { expenditures }\end{array}$ & $\begin{array}{l}1,501.90 \\
(1,179.87 \\
1,823.94)\end{array}$ & $\begin{array}{l}5,811.89 \\
(4,007.17 \\
7,616.62)\end{array}$ & $\begin{array}{l}1,728.92 \\
(1,294.10 \\
2,163.75)\end{array}$ & $\begin{array}{r}3,264.40 \\
(2,028.62 \\
4,500.19)\end{array}$ & $\begin{array}{l}348.03 \\
(141.46 \\
554.61)\end{array}$ & $\begin{array}{r}8,149.46 \\
(-3327.15 \\
12,971.78)\end{array}$ & $\begin{array}{l}347.67 \\
(257.77 \\
437.56)\end{array}$ & $\begin{array}{r}790.03 \\
(400.09 \\
1,179.97)\end{array}$ \\
\hline $\begin{array}{l}\text { Average marginal } \\
\text { effect }\end{array}$ & - & $\begin{array}{r}4,309.99 \\
(2,224.53 \\
6,395.45)\end{array}$ & - & $\begin{array}{l}1,535.48 \\
(-88.86 \\
3,159.83)\end{array}$ & - & $\begin{array}{c}7,801.43 \\
(2,806.71 \\
12,796.15)\end{array}$ & - & $\begin{array}{r}442.37 \\
(-31.76 \\
916.49)\end{array}$ \\
\hline \multicolumn{9}{|l|}{ Texas $(n=7,209)$} \\
\hline $\begin{array}{l}\text { Predicted mean } \\
\text { expenditures }\end{array}$ & $\begin{array}{c}1,792.51 \\
(1,387.38 \\
2,197.63)\end{array}$ & $\begin{array}{l}3,673.19 \\
(2,834.17 \\
4,512.21) \\
\end{array}$ & $\begin{array}{c}1,336.09 \\
(895.84 \\
1,776.34) \\
\end{array}$ & $\begin{array}{c}4,298.94 \\
(2,925.64 \\
5,672.24)\end{array}$ & $\begin{array}{c}4,493.00 \\
(-5,447.05 \\
14,433.06)\end{array}$ & $\begin{array}{c}4451.40 \\
(57.94 \\
8,844.86) \\
\end{array}$ & $\begin{array}{c}566.74 \\
(455.77 \\
677.7)\end{array}$ & $\begin{array}{c}540.21 \\
(434.11 \\
646.30)\end{array}$ \\
\hline $\begin{array}{l}\text { Average marginal } \\
\text { effect }\end{array}$ & - & $\begin{array}{c}1,880.68 \\
(692.03 \\
3,069.34)\end{array}$ & - & $\begin{array}{c}2,962.85 \\
(1,201.39 \\
4,724.30) \\
\end{array}$ & - & $\begin{array}{c}-41.60 \\
(-10,446.18 \\
10,362.98)\end{array}$ & - & $\begin{array}{c}-26.53 \\
(-221.11 \\
168.04)\end{array}$ \\
\hline \multicolumn{9}{|l|}{ New York $(n=3,394)$} \\
\hline $\begin{array}{l}\text { Predicted mean } \\
\text { expenditures }\end{array}$ & $\begin{array}{c}2,976.34 \\
(2,352.00 \\
3,600.69)\end{array}$ & $\begin{array}{r}4,952.39 \\
(3,622.41 \\
6,282.38) \\
\end{array}$ & $\begin{array}{r}3,069.23 \\
(2,328.15 \\
3,810.32)\end{array}$ & $\begin{array}{c}3,761.1 \\
(2,249.61 \\
5,272.59) \\
\end{array}$ & $\begin{array}{c}1,232.95 \\
(572.20 \\
1,893.71) \\
\end{array}$ & $\begin{array}{l}5,029.49 \\
(2,827.82 \\
7,231.16) \\
\end{array}$ & $\begin{array}{c}423.51 \\
(327.27 \\
519.74) \\
\end{array}$ & $\begin{array}{c}711.6 \\
(395.38 \\
1,027.82)\end{array}$ \\
\hline $\begin{array}{l}\text { Average marginal } \\
\text { effect }\end{array}$ & - & $\begin{array}{c}1,976.05 \\
(88.20 \\
3,863.89) \\
\end{array}$ & - & $\begin{array}{c}691.87 \\
(-1,471.57 \\
2,855.31) \\
\end{array}$ & - & $\begin{array}{c}3,796.54 \\
(1,066.29 \\
6,526.78) \\
\end{array}$ & & $\begin{array}{c}288.09 \\
(-109.00 \\
685.19)\end{array}$ \\
\hline \multicolumn{9}{|l|}{ Florida $(n=3,343)$} \\
\hline $\begin{array}{l}\text { Predicted mean } \\
\text { expenditures }\end{array}$ & $\begin{array}{l}3,008.96 \\
(2,374.86 \\
3,643.05)\end{array}$ & $\begin{array}{l}3,732.52 \\
(2,830.77 \\
4,634.26) \\
\end{array}$ & $\begin{array}{l}1,982.53 \\
(1,287.78 \\
2,677.29) \\
\end{array}$ & $\begin{array}{l}3,810.34 \\
(2,424.47 \\
5,196.21) \\
\end{array}$ & $\begin{array}{c}9,723.55 \\
(-5,560.00 \\
25,007.10)\end{array}$ & $\begin{array}{c}1,012.98 \\
(65.59 \\
1,960.36) \\
\end{array}$ & $\begin{array}{c}561.53 \\
(470.28 \\
652.78) \\
\end{array}$ & $\begin{array}{c}744.13 \\
(518.88 \\
969.38)\end{array}$ \\
\hline $\begin{array}{l}\text { Average marginal } \\
\text { effect }\end{array}$ & - & $\begin{array}{l}723.56 \\
(-706.06 \\
2,153.18)\end{array}$ & - & $\begin{array}{l}1,827.81 \\
(-129.41 \\
3,785.02)\end{array}$ & - & $\begin{array}{c}-8,710.57 \\
(-24,621.65 \\
7,200.51)\end{array}$ & - & $\begin{array}{c}182.60 \\
(-124.23 \\
489.42)\end{array}$ \\
\hline
\end{tabular}

Note: Data are from the 2001-2016 MEPS. Average marginal effect estimates of obesity are from an instrumental variables 2-part model, and expenditures are expressed in 2017 USD. The $90 \% \mathrm{Cl}$ in parentheses are adjusted for the complex design of the MEPS.

MEPS= Medical Expenditure Panel Surveys; USD=United States dollar.

and Supplementary Table 2, for all 20 states, available in online article). In California, obesity caused an increase in medical expenditures of $\$ 4,310$ (287.0\%), specifically, an increase in medical costs from $\$ 1,502$ for adults with normal weight to $\$ 5,812$ for those with obesity. The effect of obesity on medical care costs was less marked in other states. These included Texas, with a $\$ 1,881$ or $104.9 \%$ increase (from $\$ 1,793$ to $\$ 3,673)$; New York, with a $\$ 1,976$ or $66.3 \%$ increase (from $\$ 2,976$ to $\$ 4,952$ ); and Florida, with a $\$ 724$ or $24.0 \%$ increase (from $\$ 3,009$ to $\$ 3,733$ ), although the estimate for Florida was not statistically significant at $\mathrm{P}<0.1$.

\section{MEDICAL EXPENDITURES BY PAYER AT STATE LEVEL}

As at the national level, obesity-related medical expenditures at the state level tended to be greater for public health insurance payments than private health insurance payments, with only a small portion of the costs paid out of pocket by individuals (Table 3 and Supplementary Table 3, available in online article). In California, obesity raised public health insurance payments by $\$ 7,801$, annual private health insurance payments by $\$ 1,535$, and out-of-pocket payments by $\$ 442$ for each adult with obesity; the corresponding estimates for New York residents were $\$ 3,797$, \$692, and $\$ 288$, respectively. For both California and New York, the 


\section{TABLE 4 Aggregate Total Medical Expenditure Due to Obesity in the United States and Separately for the Top 4 Most Populous States (Billions of 2017 USD)}

\begin{tabular}{|c|c|c|c|c|c|c|c|c|}
\hline \multicolumn{3}{|c|}{ 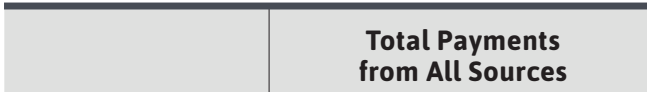 } & \multicolumn{2}{|c|}{ Private Payments } & \multicolumn{2}{|c|}{ Public Payment } & \multicolumn{2}{|c|}{ Out-of-Pocket Payments } \\
\hline \multicolumn{9}{|c|}{ United States $(n=63,508)$} \\
\hline 2001 & 124.24 & $(92.92,155.55)$ & 68.25 & $(45.83,90.67)$ & 15.50 & $(7.34,23.66)$ & 12.44 & $(6.42,18.46)$ \\
\hline 2002 & 131.83 & $(98.74,164.91)$ & 70.96 & $(46.81,95.12)$ & 28.20 & $(11.84,44.55)$ & 12.78 & $(6.46,19.10)$ \\
\hline 2003 & 138.50 & $(103.18,173.83)$ & 74.51 & $(49.50,99.53)$ & 26.48 & $(13.75,39.22)$ & 14.70 & $(7.30,22.09)$ \\
\hline 2004 & 164.02 & $(120.05,207.98)$ & 91.29 & $(59.19,123.38)$ & 29.36 & $(14.00,44.72)$ & 16.34 & $(8.21,24.46)$ \\
\hline 2005 & 156.97 & $(116.25,197.69)$ & 85.48 & $(54.51,116.46)$ & 30.09 & $(15.95,44.24)$ & 16.56 & $(8.54,24.58)$ \\
\hline 2006 & 167.30 & $(124.74,209.86)$ & 88.24 & $(58.14,118.34)$ & 35.35 & $(19.00,51.70)$ & 18.03 & $(9.38,26.68)$ \\
\hline 2007 & 188.73 & $(138.17,239.28)$ & 102.98 & $(64.36,141.60)$ & 22.62 & $(12.14,33.11)$ & 16.82 & $(8.63,25.00)$ \\
\hline 2008 & 182.52 & $(133.60,231.45)$ & 97.55 & $(62.57,132.54)$ & 27.96 & $(12.53,43.40)$ & 17.39 & $(8.79,25.99)$ \\
\hline 2009 & 207.88 & $(156.99,258.76)$ & 108.10 & $(71.10,145.11)$ & 39.88 & $(22.15,57.61)$ & 16.84 & $(8.63,25.06)$ \\
\hline 2010 & 227.14 & $(172.11,282.16)$ & 117.71 & $(79.55,155.87)$ & 27.00 & $(15.20,38.79)$ & 17.58 & $(9.14,26.01)$ \\
\hline 2011 & 216.39 & $(163.52,269.25)$ & 122.75 & $(82.12,163.38)$ & 39.95 & $(21.10,58.81)$ & 16.95 & $(8.75,25.14)$ \\
\hline 2012 & 228.15 & $(169.84,286.46)$ & 123.72 & $(80.17,167.27)$ & 37.41 & $(18.66,56.15)$ & 18.94 & $(9.79,28.09)$ \\
\hline 2013 & 263.48 & $(193.95,333.01)$ & 128.70 & $(82.82,174.59)$ & 56.95 & $(29.31,84.59)$ & 19.74 & $(10.89,28.60)$ \\
\hline 2014 & 228.97 & $(168.84,289.10)$ & 115.17 & $(74.61,155.73)$ & 49.55 & $(25.93,73.16)$ & 16.45 & $(8.93,23.97)$ \\
\hline 2015 & 245.94 & $(179.41,312.48)$ & 132.94 & $(86.24,179.64)$ & 60.31 & $(31.08,89.54)$ & 16.29 & $(8.42,24.16)$ \\
\hline 2016 & 260.56 & $(195.35,325.77)$ & 139.36 & $(90.67,188.05)$ & 57.92 & $(30.00,85.84)$ & 20.01 & $(11.19,28.83)$ \\
\hline \multicolumn{9}{|c|}{ Comparison of average trends } \\
\hline 2001-2016 Avg & 193.97 & $(148.92,239.03)$ & 103.20 & $(70.54,135.86)$ & 36.49 & $(20.88,52.10)$ & 16.70 & $(8.88,24.52)$ \\
\hline 2001-2005 Avg (1) & 152.88 & $(115.38,190.38)$ & 83.31 & $(55.94,110.67)$ & 26.79 & $(13.95,39.63)$ & 15.55 & $(7.98,23.13)$ \\
\hline 2006-2010 Avg (2) & 194.63 & $(148.21,241.05)$ & 103.40 & $(69.48,137.32)$ & 30.15 & $(17.76,42.54)$ & 17.36 & $(9.07,25.65)$ \\
\hline 2011-2016 Avg (3) & 227.67 & $(178.11,277.23)$ & 119.61 & $(84.15,155.07)$ & 49.86 & $(26.93,72.80)$ & 17.10 & $(9.87,24.34)$ \\
\hline (3)-(1) & 74.79 & $(51.53,98.04)$ & 36.30 & $(20.54,52.07)$ & 23.08 & $(12.13,34.02)$ & 1.55 & $(0.13,2.97)$ \\
\hline (3)-(2) & 33.04 & $(13.63,52.45)$ & 16.22 & $(4.45,27.98)$ & 19.71 & $(7.85,31.57)$ & -0.26 & $(-1.80,1.29)$ \\
\hline \multicolumn{9}{|l|}{ California $(n=10,870)$} \\
\hline 2001-2016 Avg & 4.38 & $(2.35,6.42)$ & 0.97 & $(0.00,1.95)$ & 1.98 & $(0.84,3.13)$ & 0.45 & $(-0.01,0.91)$ \\
\hline 2016 & 5.26 & $(2.64,7.89)$ & 1.09 & $(-0.11,2.30)$ & 4.73 & $(1.36,8.11)$ & 0.50 & $(0.01,0.99)$ \\
\hline \multicolumn{9}{|l|}{ Texas $(n=7,209)$} \\
\hline 2001-2016 Avg & 1.85 & $(0.67,3.02)$ & 1.94 & $(0.82,3.06)$ & -0.01 & $(-0.53,0.52)$ & -0.03 & $(-0.22,0.17)$ \\
\hline 2016 & 2.56 & $(0.91,4.21)$ & 2.89 & $(1.19,4.59)$ & -0.03 & $(-1.20,1.14)$ & -0.04 & $(-0.29,0.22)$ \\
\hline \multicolumn{9}{|l|}{ New York $(n=3,394)$} \\
\hline 2001-2016 Avg & 0.99 & $(0.06,1.92)$ & 0.22 & $(-0.47,0.92)$ & 0.42 & $(0.12,0.73)$ & 0.14 & $(-0.05,0.33)$ \\
\hline 2016 & 1.14 & $(0.12,2.15)$ & 0.25 & $(-0.55,1.05)$ & 0.44 & $(0.17,0.71)$ & 0.16 & $(-0.06,0.38)$ \\
\hline \multicolumn{9}{|l|}{ Florida $(n=3,343)$} \\
\hline 2001-2016 Avg & 0.34 & $(-0.33,1.01)$ & 0.61 & $(-0.03,1.25)$ & -0.55 & $(-1.79,0.7)$ & 0.09 & $(-0.06,0.23)$ \\
\hline 2016 & 0.67 & $(-0.73,2.06)$ & 1.31 & $(-0.17,2.79)$ & -0.53 & $(-1.65,0.59)$ & 0.18 & $(-0.11,0.46)$ \\
\hline
\end{tabular}

Note: Data are from the 2001-2016 MEPS. The $90 \% \mathrm{Cls}$ in parentheses are adjusted for the complex design of the MEPS.

Avg $=$ average; $M E P S=$ Medical Expenditure Panel Surveys; USD=United States dollar 
estimates for private payments and out-of-pocket payments were not statistically significant. Further, although estimates were reported by payer for 20 states, caution is warranted in the interpretation of results by payer at the state level, given that the estimates were less precise due to the smaller sample sizes.

\section{AGGREGATE MEDICAL EXPENDITURES DUE TO ADULT OBESITY AT STATE LEVEL}

Aggregate medical expenditures due to obesity at the state level are presented in Table 4 and Supplementary Table 4 (available in online article). In 2016, California had the highest total medical expenditure due to obesity, estimated at $\$ 5.3$ billion ( $\$ 4.7$ billion paid by public insurance, $\$ 1.1$ billion paid by private insurance-estimate not statistically significant-and an estimated $\$ 0.5$ billion paid by patients out of pocket), followed by Texas, with total obesity expenditures estimated at $\$ 2.6$ billion.

\section{Discussion}

This study provides the most up-to-date and comprehensive evidence of the causal effects of obesity on medical care costs in the United States at the national and state levels. We estimated 2-part models of instrumental variables that exploit the heritable component of weight, using the BMI of a biological child as an instrument for the weight of the parent, based on data from the MEPS for 2001-2016.

Estimates from the models indicated that adults with obesity incurred $\$ 2,505$ higher annual medical costs, doubling their medical expenditures compared with people with normal weight. The increase in costs rose with class of obesity.

The effects of obesity raised costs in all major categories of medical care, with particularly large increases in inpatient services and prescription drug expenditures. Most of the increase in medical expenditures associated with adult obesity was paid by third-party payers, accounting for $88.5 \%$ of the total cost increase. This implies that obesity imposes substantial negative externalities, which represents an economic rationale for government intervention to prevent and reduce obesity. ${ }^{28}$ The effect of obesity on medical expenditures, both overall and by type of medical service, tended to be greater for public than for private health insurance expenditures. A possible explanation for the higher costs of obesity to public providers may be that those covered by public health insurance are in worse health (i.e., more likely to have chronic conditions and functional limitations) than those covered by private health insurance, and thus have higher medical care utilization. ${ }^{42}$
The aggregate medical costs due to obesity more than doubled over the 16-year period from 2001 to 2016; in 2016 , obesity in adults was responsible for $\$ 260.6$ billion in medical expenditures in the United States. The increase in aggregate medical costs over time was likely due to a combination of factors such as increases in the size of the adult population of the United States, prevalence of obesity, cost of health care, emerging new (and more expensive) treatments, increased clinical complications in people with obesity (e.g., number and type of comorbidities), and potentially an increase in the number of health care services provided to individuals with obesity.

\section{LIMITATIONS}

This study has several limitations. As with all instrumental variables models, one must be cautious about instrument validity. We acknowledge that the instrument of child BMI could be correlated with unobserved factors that are correlated with residual parental medical expenditures. Our assumption that child BMI is not correlated with residual parental medical expenditures is supported by the finding that nontransmitted parental alleles for BMI have no detectable effect on child BMI ${ }^{34,35}$; this is consistent with the assumption that the effect of parental BMI on other parental outcomes does not affect the weight of the child.

We were able to estimate our instrumental variables models only for adults with at least 1 biological child residing in their household, which restricted the age range of the sample. This may have affected the generalizability of the results to the entire adult population with obesity in the United States.

Another factor that could limit the generalizability of the results is that we used genetic variation in weight to identify the effect of obesity on medical care costs; to the extent that variation in weight due to other factors had a different effect on medical care costs, our specific estimates may not generalize.

To estimate the effect of obesity, it would be ideal to use a more accurate measure of adiposity, such as percentage body fat; however, we were limited by the fact that BMI, which is a suboptimal but commonly used estimate of adiposity ${ }^{43,44}$ is the only measure of obesity available in the MEPS. We could not conduct a longitudinal analysis; MEPS panels change every 2 calendar years, which is a period too short to observe within-person changes in BMI and medical expenditures. Given that height and weight used to calculate BMI are self-reported in the MEPS, it is likely that the prevalence of obesity was underestimated in the study ${ }_{1}^{45}$ resulting in potential underestimation of the total medical costs due to obesity. 
Because limitations with MEPS sample size prevented precise estimations for all states, caution should be used in the interpretation of the results for states with smaller sample sizes, as some of the estimates may be imprecise, especially for subanalyses by class of obesity or payer type.

\section{POLICY IMPLICATIONS}

Our estimates of the causal effect of obesity on medical care costs suggest that effective interventions to prevent and reduce obesity may be more cost-effective than shown in previous studies. The high costs of obesity to public health insurance programs represent an externality, which is an economic rationale for government intervention (e.g., for government to implement effective methods of preventing and reducing obesity).

\section{Conclusions}

This analysis contributes to the literature on obesity costs by providing up-to-date and comprehensive estimates of the causal effect of obesity (national and by state, overall and by class of obesity) on medical expenditures, overall as well as by type of medical services and type of payers. The results indicate that the effects of obesity raise medical care costs substantially for every category of expenditure (outpatient, inpatient, and prescription drugs), and for both public health insurance programs and private health insurers.

\section{DISCLOSURES}

Novo Nordisk financed the development of the study design, analysis, and interpretation of data, as well as writing support of the manuscript. Cawley, Biener, and Meyerhoefer received financial support from Novo Nordisk to conduct the research study on which this manuscript is based. Smolarz and Ramasamy are employees of Novo Nordisk. Ding and Zvenyach have no conflicts to declare.
Our research has been presented as a poster at the 2020 AcademyHealth Annual Research Meeting (Virtual), July 28August 6, 2020.

\section{ACKNOWLEDGMENTS}

The authors would like to thank Jonathan S. Davis, Daniela Geba, and Rebecca Hahn of KJT Group for their medical writing assistance and support.

\section{REFERENCES}

1. Revels S, Kumar SAP, Ben-Assuli O. Predicting obesity rate and obesityrelated healthcare costs using data analytics. Health Policy Technol. 2017;6(2):198-207.

2. Flegal KM, Kruszon-Moran D, Carroll MD, Fryar CD, Ogden CL. Trends in obesity among adults in the United States, 2005 to 2014. JAMA. 2016;315(21):2284-91.

3. NCD Risk Factor Collaboration (NCD-RisC). Trends in adult bodymass index in 200 countries from 1975 to 2014: a pooled analysis of 1698 population-based measurement studies with 19.2 million participants. Lancet. 2016;387(10026):1377-96.

4. Hales CM, Carroll MD, Fryar CD, Ogden CL. Prevalence of obesity and severe obesity among adults: United States, 2017-2018. NCHS Data Brief. 2020(360):1-8.

5. Hruby A, Hu FB. The epidemiology of obesity: a big picture. Pharmacoeconomics. 2015;33(7):673-89.

6. Kyrgiou M, Kalliala I, Markozannes G, et al. Adiposity and cancer at major anatomical sites: umbrella review of the literature. BMJ. 2017;356:j477.

7. Xu H, Cupples LA, Stokes A, Liu CT. Association of obesity with mortality over 24 years of weight history: findings from the Framingham Heart Study. JAMA Netw Open. 2018;1(7):e184587.

8. Wang YC, McPherson K, Marsh T, Gortmaker SL, Brown M. Health and economic burden of the projected obesity trends in the USA and the UK. Lancet. 2011;378(9793):815-25.
9. Li Q, Blume SW, Huang JC, Hammer M, Ganz ML. Prevalence and healthcare costs of obesity-related comorbidities: evidence from an electronic medical records system in the United States. J Med Econ. 2015;18(12):1020-28.

10. Hong YR, Huo J, Desai R, Cardel M, Deshmukh AA. Excess costs and economic burden of obesity-related cancers in the United States. Value Health. 2019;22(12):1378-86.

11. Kim DD, Basu A. Estimating the medical care costs of obesity in the United States: systematic review, meta-analysis, and empirical analysis. Value Health. 2016;19(5):602-13.

12. Kamble PS, Hayden J, Collins J, et al. Association of obesity with healthcare resource utilization and costs in a commercial population. Curr Med Res Opin. 2018;34(7):1335-43.

13. Suehs BT, Kamble P, Huang J, et al. Association of obesity with healthcare utilization and costs in a Medicare population. Curr Med Res Opin. 2017;33(12):2173-80.

14. Finkelstein EA, Trogdon JG, Cohen JW, Dietz W. Annual medical spending attributable to obesity: payer-and servicespecific estimates. Health Aff (Millwood). 2009;28(5):w822-31.

15. Su W, Huang J, Chen F, et al. Modeling the clinical and economic implications of obesity using microsimulation. J Med Econ. 2015;18(11):886-97.

16. Biener A, Cawley J, Meyerhoefer C. The impact of obesity on medical care costs and labor market outcomes in the U.S. Clin Chem. 2018;64(1):108-17.

17. United Health Foundation, the American Public Health Association and Partnership for Prevention. The future costs of obesity: national and state estimates of the impact of obesity on direct health care expenses. November 2009. Accessed December 4, 2020. http://www.nccor.org/downloads/ CostofObesityReport-FINAL.pdf 
18. Wang YC, Pamplin J, Long MW, Ward ZJ, Gortmaker SL, Andreyeva T. Severe obesity In adults cost state medicaid programs nearly \$8 billion In 2013. Health Aff (Millwood). 2015;34(11):1923-31.

19. Trogdon JG, Finkelstein EA, Feagan CW, Cohen JW. State- and payer-specific estimates of annual medical expenditures attributable to obesity. Obesity. 2012;20(1):214-20.

20. Harris BH, Werman A. Obesity costs evident at the state level. Brookings. December 12, 2014. Accessed December 4, 2020. https://www.brookings. edu/blog/up-front/2014/12/12/ obesity-costs-evident-at-the-state-level/

21. Tsai AG, Williamson DF, Glick HA. Direct medical cost of overweight and obesity in the USA: a quantitative systematic review. Obes Rev. 2011;12(1):50-61.

22. Andreyeva T, Sturm R, Ringel JS. Moderate and severe obesity have large differences in health care costs. Obes Res. 2004;12(12):1936-43.

23. Kurz CF, Laxy M. Application of Mendelian randomization to investigate the association of body mass index with health care costs. Med Decis Making. 2020;40(2):156-69.

24. Black N, Hughes R, Jones AM. The health care costs of childhood obesity in Australia: an instrumental variables approach. Econ Hum Biol. 2018;31:1-13.

25. Biener AI, Cawley J, Meyerhoefer C. The medical care costs of obesity and severe obesity in youth: an instrumental variables approach. Health Economics. 2020;29(5):624-39.

26. Biener A, Cawley J, Meyerhoefer C. The high and rising costs of obesity to the US health care system. J Gen Intern Med. 2017;32(Suppl 1):6-8.
27. Cawley J, Meyerhoefer C. The medical care costs of obesity: an instrumental variables approach. J Health Econ. 2012;31(1):219-30.

28. Cawley J, Meyerhoefer C, Biener A, Hammer M, Wintfeld N. Savings in medical expenditures associated with reductions in body mass index among U.S. adults with obesity, by diabetes status. Pharmacoeconomics. 2015;33(7):707-22.

29. Manning WG, Mullahy J. Estimating log models: to transform or not to transform? J Health Econ. 2001;20(4):461-94.

30. Elks CE, den Hoed M, Zhao JH, et al. Variability in the heritability of body mass index: a systematic review and metaregression. Front Endocrinol (Lausanne). 2012;3:29.

31. Waalen J. The genetics of human obesity. Transl Res. 2014;164(4):293-301.

32. Yengo L, Sidorenko J, Kemper KE, et al. Meta-analysis of genome-wide association studies for height and body mass index in 700000 individuals of European ancestry. Hum Mol Genet. 2018;27(20):3641-49.

33. Silventoinen K, Rokholm B, Kaprio J, Sorensen TI. The genetic and environmental influences on childhood obesity: a systematic review of twin and adoption studies. Int J Obes (Lond). 2010;34(1):29-40.

34. Kong A, Thorleifsson G, Frigge ML, et al. The nature of nurture: effects of parental genotypes. Science. 2018;359(6374):424-28.

35. Richmond RC, Timpson NJ, Felix JF, et al. Using genetic variation to explore the causal effect of maternal pregnancy adiposity on future offspring adiposity: a Mendelian randomisation study. PLoS Med. 2017;14(1):e1002221.

36. Locke AE, Kahali B, Berndt SI, et al. Genetic studies of body mass index yield new insights for obesity biology. Nature. 2015;518(7538):197-206.
37. Speliotes EK, Willer CJ, Berndt SI, et al. Association analyses of 249,796 individuals reveal 18 new loci associated with body mass index. Nat Genet. 2010;42(11):937-48.

38. Agency for Healthcare Research and Quality. Accounting for clustering in the analysis of MEPS data: frequently asked questions (FAQ). 2017. Accessed December 4, 2020. https://meps.ahrq.gov/survey comp/hc_clustering_faq.pdf

39. Williams RL. A note on robust variance estimation for cluster-correlated data. Biometrics. 2000;56(2):645-46.

40. Judkins DR. Fay's method for variance estimation. J Off Stat. 1990;6(3):223-39.

41. U.S. Department of Health \& Human Services. Medical expenditure panel survey. April 2019. Accessed December 4, 2020. https://www.meps.ahrq.gov/mepsweb/about meps/survey back.jsp

42. Hayes S, Salzberg C, McCarthy D, et al. High-need, high-cost patients: who are they and how do they use health care? A population-based comparison of demographics, health care use, and expenditures. Issue Brief (Commonw Fund). 2016;26:1-14.

43. Burkhauser RV, Cawley J. Beyond BMI: the value of more accurate measures of fatness and obesity in social science research. J Health Econ. 2008;27(2):519-29.

44. O'Neill D. Measuring obesity in the absence of a gold standard. Econ Hum Biol. 2015;17:116-28.

45. Maukonen M, Männistö S, Tolonen H. A comparison of measured versus selfreported anthropometrics for assessing obesity in adults: a literature review. Scand J Public Health. 2018;46(5):565-79. 